UDC 519.6

\title{
Simulation of coastal aerodynamics taking into account forest plantations*
}

\author{
Yu.V. Belova**, E.A. Protsenko ${ }^{* * *}$, A.M. Atayan, I.A. Kurskaya** \\ Don State Technical University, Rostov-on-Don, Russia \\ Taganrog Institute after A.P. Chekhov (branch) of RSUE, Taganrog, Russia
}

The aim of the work is to study the influence of forest plantations on the distribution of pollutants in the ground layer of the atmosphere. The model that takes into account a variety of factors: the presence of forest plantations, the variability of pressure, density and temperature, the presence of a multicomponent impurity, etc., was proposed for the numerical modeling of the process of transferring air pollutants to air. The scheme obtained as a result of a linear combination of the central difference scheme and the «CABARET» scheme was constructed to approximate the convection operator in this paper. The use of cabaret schemes allowed to develop the mathematical model that has the property of stability for a wider class of input parameters. The constructed algorithms are implemented in the form of the software complex that allows to determine the influence of the forest plantations on the distribution of pollutants under the influence of ascending air currents. The developed model, the algorithms that implement it, and the software complex constructed allowed to carry out the numerical experiments that simulate the distribution of pollutants in the surface layer of the atmosphere in the presence of forest plantations. The influence of the presence of vegetation on the distribution of pollutants under the action of ascending air currents is studied: pollutants under the influence of ascending air currents rise upwards in the area of forest plantations. The influence of the forest plantations area width on the air velocity and pollutants concentration fields is studied. An analysis of the results of numerical experiments allows to conclude that the distribution of pollutants in a multicomponent air environment is most significantly affected by the density of vegetation, and insignificantly influenced by the width of the forest plantations area.

Keywords: numerical modeling, process of transferring air pollutants, central difference scheme, «CABARET» scheme, convection operator

Introduction. The growing anthropogenic load adversely affects to the state of the ground layer of the atmosphere. In conditions of modern reality, it is impossible to avoid receipt of pollutants into the air ecosystem. At present, a wide range of theoretical studies on atmospheric air pollution based directly on the solution of differential equations is being conducted. Problems of this type are quite complex from a practical point of view and very significant. Mathematical formulation is not universal enough in works devoted to these problems.

\footnotetext{
* The research is done with the financial support from the RSF, Project No. 17-11-01286.

** E-mail: yvbelova@yandex.ru.

*** E-mail: eapros@rambler.ru.
} 
The transfer of impurities in the atmosphere is significantly influenced by the wind regime and temperature stratification of the ground layer of the atmosphere, as well as meteorological conditions. Analysis and forecast of pollutants dispersion in the atmosphere is necessary for the rational allocation of residential areas and industrial enterprises whose production waste affects health and comfortable living conditions. The problems devoted to the analysis of atmospheric air require a large amount of initial data and complex mathematical methods of solution. In connection with the growth of anthropogenic impact on ecosystems, the actual problem of research is the improvement of mathematical models intended for assessing the state of the air environment. The mathematical modeling is effective way to solve this problem. It allows to numerically calculate the propagation fields of pollutants for various widths and densities of forest massifs in the ground layer of the atmosphere. The use of the interrelated mathematical models complex of the variability of the atmosphere gas and aerosol composition makes it possible to predict possible prospects for the development of the ecosystem and the consequences for the development of building projects, gardening, etc.

Significant factors in the development of aerial ecosystems are the aerodynamic processes that determine the transfer of pollutants and mixing of the air.

Mathematical model. The mathematical model of the impurity propagation process, presented in $[1,2]$, gives a theoretical description of this process, takes into account a number of physical factors that influence the transfer of the impurity, and allows one to predict its course and consequences.

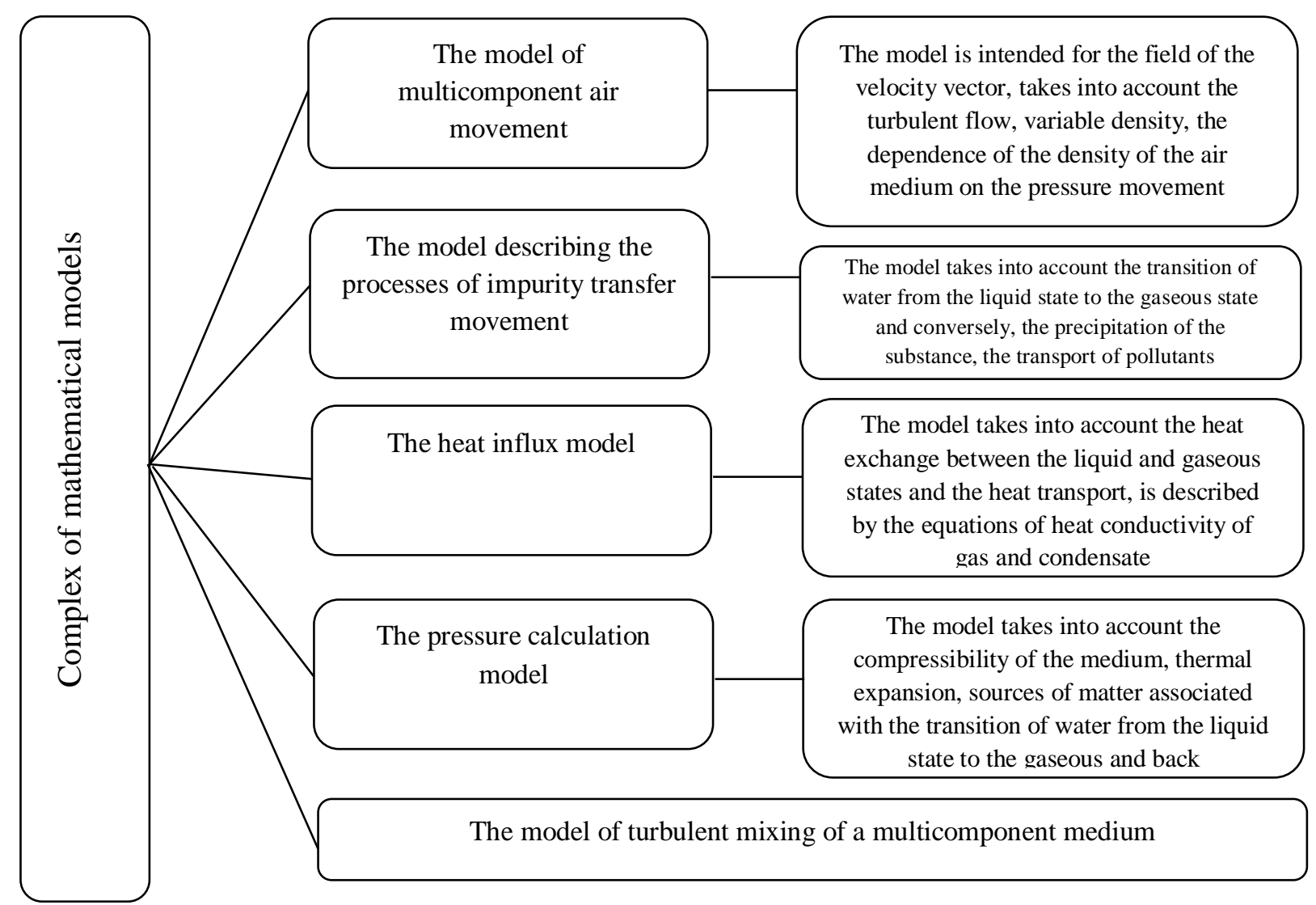

Fig. 1. Elements of the interrelated models complex 
Impurity scattering takes into account turbulence, heat and humidity propagation, the presence of forest massifs in the presented model. These additional conditions form a system and begin to act as a single set. Developed models also take into account the presence of forest plantations. Using the «CABARET» schemes allowed the authors of this work to develop a mathematical model that has the property of stability for a wider class of input parameters [3].

A set of models used to describe the motion of the air environment and the impurities propagation in it are presented in Figure 1. The initial equations of the model are shown in Table 1.

Table 1. Initial model equations

\begin{tabular}{|l|c|}
\hline $\begin{array}{l}\text { The equation of motion (the Navier- } \\
\text { Stokes equation) }\end{array}$ & $\frac{d v_{j}}{d t}=-\frac{1}{\rho} \frac{\partial P}{\partial x_{j}}+\operatorname{div}\left(\mu \operatorname{grad}\left(v_{j}\right)\right)-g_{i}$ \\
\hline $\begin{array}{l}\text { The equation of continuity (transport of } \\
\text { matter) }\end{array}$ & $\frac{\partial \rho}{\partial t}+\operatorname{div}(\rho \vec{v})=\operatorname{div}(\mu \operatorname{grad}(\rho))+I_{\rho}$ \\
\hline $\begin{array}{l}\text { The equation of state (an analog of the } \\
\text { Mendeleev-Clapeyron equation) }\end{array}$ & $P=\sum_{i} \rho_{i} R T / M_{i}$ \\
\hline The equation of impurity transport & $\frac{d \varphi_{i}}{d t}=\operatorname{div}\left(\mu \operatorname{grad}\left(\varphi_{i}\right)\right)+I_{\varphi}$ \\
\hline The equation of heat influx & $\frac{d Q}{d t}=\operatorname{div}(\mu \operatorname{grad}(Q))+\operatorname{div}(\lambda \operatorname{grad}(T))+I_{Q}$ \\
\hline The equation of the turbulence model & $v_{S G S}=\left(C_{S} \Delta\right)^{2} S$ \\
\hline
\end{tabular}

In the Table $1 \varphi_{i}$ is the volume fractions of the $\mathrm{i}$-th phases: air, water in the gaseous state, gas at the source, water in the liquid state, soot, $v_{j}$ the projection of the air velocity vector on the axis $O x_{j}$, $j=1,2,3 ; \lambda$ the coefficient of thermal conductivity, $R$ the universal gas constant, $T$ the gas phase temperature, $Q$ the thermal energy, $\mu$ the coefficient of turbulent diffusion, $\rho$ the density, $M$ the molar mass, $I$ the source function, $P$ the pressure [4].

Difference scheme. The difference method was constructed to approximate the developed model [5-6]. Comparison of simulation results with full-scale data showed that the calculation error for the proposed model is $10-15 \%$ [1].

If the Peclet number is less than two, the central difference schemes are most effective. When solving applied problems, the application of these schemes entails an increase in the nets size and a significant increase in labor intensity as a consequence. Also, to solve this class of problems, it is possible to introduce dissipative terms into the schemes, which entails a significant decrease in the accuracy of the solution, and this approach is highly undesirable. The «left corner» scheme is an example of a scheme which has the dissipative members. The «CABARET» scheme that has the property of stability and nondissipativity was developed to overcome these problems. The scheme obtained as a result of the linear combination of the central difference scheme and the cabaret scheme is used for the convection operator.

Let consider the transfer equation 


$$
\frac{\partial q}{\partial t}+u \frac{\partial q}{\partial x}=0
$$

where $t \in[0, T], x \in[0, L], q(0, x)=q^{0}(x), q(t, 0)=q(t, L)=0, u=$ const .

Let introduce the uniform grid $\omega=\bar{\omega}_{h} \times \omega_{\tau}$, where $\bar{\omega}_{h}=\left\{x_{i} \mid x_{i}=i h, i=0,1, \ldots, N, N h=L\right\}$, $\omega_{\tau}=\left\{t_{j} \mid j=0,1, \ldots\right\}, \tau=t_{n+1}-t_{n}=$ const.

To solve the problem numerically, it is possible to use the following finite-difference schemes [1]

- the «anti-flow» scheme or for $u>0$ the left corner [1]

$$
\frac{q_{i}^{n+1}-q_{i}^{n}}{\tau}+u \frac{q_{i}^{n}-q_{i-1}^{n}}{h}=0
$$

- the central difference scheme

$$
\frac{q_{i}^{n+1}-q_{i}^{n}}{\tau}+u \frac{q_{i+1}^{n}-q_{i-1}^{n}}{2 h}=0
$$

- the «CABARET» scheme [2]

$$
\frac{q_{i}^{n+1}-q_{i}^{n}}{2 \tau}+\frac{q_{i-1}^{n}-q_{i-1}^{n-1}}{2 \tau}+u \frac{q_{i}^{n}-q_{i-1}^{n}}{h}=0 .
$$

The scheme obtained as a result of a linear combination of the central difference scheme (3) and the «CABARET» scheme can be used to solve the convection problem (4)

$$
\begin{gathered}
\frac{1}{2}\left(\frac{q_{i}^{n+1}-q_{i}^{n}}{\tau}+u \frac{q_{i+1}^{n}-q_{i-1}^{n}}{2 h}\right)+\frac{q_{i}^{n+1}-q_{i}^{n}}{2 \tau}+\frac{q_{i-1}^{n}-q_{i-1}^{n-1}}{2 \tau}+u \frac{q_{i}^{n}-q_{i-1}^{n}}{h}=0 ; \\
\frac{q_{i}^{n+1}-q_{i}^{n}}{\tau}+\frac{q_{i-1}^{n}-q_{i-1}^{n-1}}{2 \tau}+u \frac{q_{i+1}^{n}+4 q_{i}^{n}-5 q_{i-1}^{n}}{4 h}=0 .
\end{gathered}
$$

The grid pattern for the proposed scheme is shown in Fig. 1.

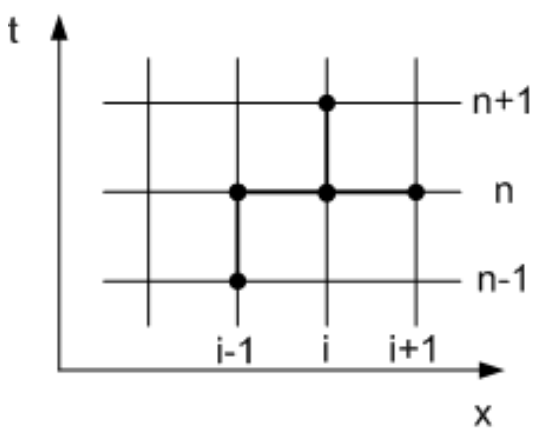

Fig. 1. The grid template on which the new scheme is define

Let find the numerical solutions based on the schemes (2)-(5) of the model problem with initial conditions $q^{0}(x)=h(20-\mathrm{x})$, where $h(\mathrm{x})$ is the Heaviside function. Fig. 2 shows the solutions of the model problem (1 - numerical solution, 2 - exact solution). 

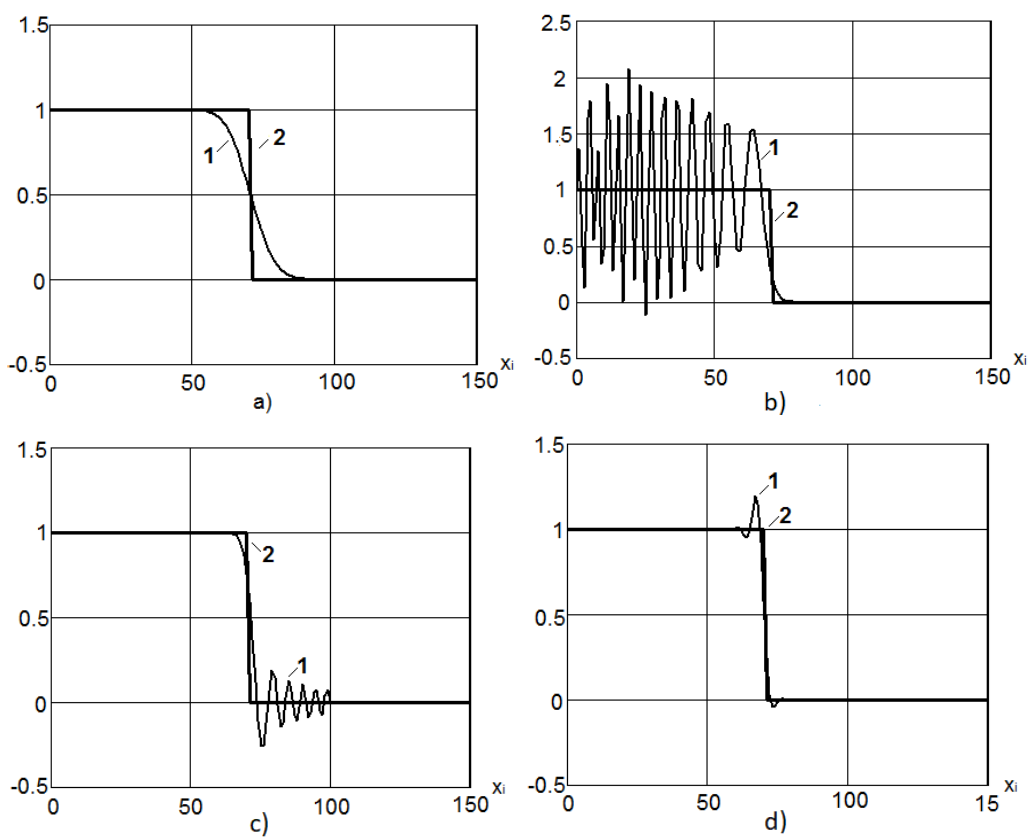

Fig. 2. The solutions of the model problem based on the schemes (2) - (5): a) the left difference scheme; b) the central difference scheme; c) the «CABARET» scheme; d) the proposed difference scheme

It is seen from the figure that the left difference scheme approximates the «jump» insufficiently accurately, the central difference scheme is unstable, the solution obtained on the basis of the «CABARET» scheme has oscillations (entropy perturbations) [3]. The proposed difference scheme gives the most accurate solution of the model problem. The left difference scheme has the order of approximation $O(\tau+h)$, the central difference scheme approximates the continuous model with the order $O\left(\tau+h^{2}\right)$, scheme «CABARET» - with the order $O\left(\tau^{2}+h^{2}\right)$.

The stability of the difference scheme. Investigate the stability of scheme (5) by the method of harmonics. Let $q_{i}^{n}=\varphi^{n} \cdot e^{j k i}$, where $j=\sqrt{-1}$, substitute in (5):

$$
\begin{gathered}
\frac{\varphi-1}{\tau}+\frac{e^{-j k}-e^{-j k} / \varphi}{2 \tau}+u \frac{e^{j k}+4-5 e^{-j k}}{4 h}=0 \\
\varphi^{2}+\left(\left(-\frac{1}{2}+\frac{u \tau}{h}\right)(1-\cos k)-\frac{1}{2}+j \frac{\sin k}{2}\left(-1+\frac{3 u \tau}{h}\right)\right) \varphi-\frac{e^{-j k}}{2}=0 .
\end{gathered}
$$

Solve the quadratic equation with respect to $\varphi$ :

$$
\begin{gathered}
\varphi_{1,2}=\left(\frac{1}{4}-\frac{u \tau}{h}\right)(1-\cos k)+\frac{1}{4}-j \frac{\sin k}{4}\left(-1+\frac{3 u \tau}{h}\right) \pm \\
\pm \sqrt{\left(\left(\frac{1}{4}-\frac{u \tau}{h}\right)(1-\cos k)+\frac{1}{4}-j \frac{\sin k}{4}\left(-1+\frac{3 u \tau}{h}\right)\right)^{2}+\frac{e^{-j k}}{2}} .
\end{gathered}
$$

Let $\frac{u \tau}{h}=x$, then 


$$
\begin{gathered}
\varphi_{1,2}=\left(\frac{1}{4}-x\right)(1-\cos k)+\frac{1}{4}-j \frac{\sin k}{4}(3 x-1) \pm \\
\pm \sqrt{\left(\left(\frac{1}{4}-x\right)(1-\cos k)+\frac{1}{4}-j \frac{\sin k}{4}(3 x-1)\right)^{2}+\frac{e^{-j k}}{2}} .
\end{gathered}
$$

Consider the case $x=0$ :

$$
\varphi_{1,2}=\frac{1}{2}-\frac{e^{-j k}}{4} \pm \sqrt{\left(\frac{1}{2}-\frac{e^{-j k}}{4}\right)^{2}+\frac{e^{-j k}}{2}}=\frac{1}{2}-\frac{e^{-j k}}{4} \pm\left(\frac{1}{2}+\frac{e^{-j k}}{4}\right) .
$$

Hence obtain: $\varphi_{1}=1, \varphi_{2}=-e^{-j k} / 2$, consequently, $\varphi_{2}$ is not the solution. Denote $\psi(x, k)$ absolute values of functions $\varphi_{1}(x, k)$. Investigate the behavior of the values of functions $\psi(x, k)$. Take the values $k \in[0,2 \pi]$ with step $\pi / 6$ and values $x \in[0,1]$ with step 0.1 . Write the obtained

\begin{tabular}{|c|c|c|c|c|c|c|c|}
\hline$k$ & 0 & $\pi / 6$ & $\pi / 3$ & $\pi / 2$ & $2 \pi / 3$ & $5 \pi / 6$ & $\pi$ \\
\hline 0 & 1 & 1 & 1 & 1 & 1 & 1 & 1 \\
\hline 0.1 & 1 & 0.991 & 0.966 & 0.924 & 0.866 & 0.791 & 0.707 \\
\hline 0.2 & 1 & 0.984 & 0.939 & 0.877 & 0.812 & 0.755 & 0.707 \\
\hline 0.3 & 1 & 0.977 & 0.918 & 0.845 & 0.781 & 0.737 & 0.707 \\
\hline 0.4 & 1 & 0.973 & 0.902 & 0.821 & 0.759 & 0.724 & 0.707 \\
\hline 0.5 & 1 & 0.967 & 0.888 & 0.802 & 0.740 & 0.712 & 0.707 \\
\hline 0.6 & 1 & 0.964 & 0.877 & 0.785 & 0.721 & 0.698 & 0.707 \\
\hline 0.7 & 1 & 0.961 & 0.868 & 0.770 & 0.699 & 0.670 & 0.707 \\
\hline 0.8 & 1 & 0.959 & 0.861 & 0.755 & 0.648 & 0.428 & 0.378 \\
\hline 0.9 & 1 & 0.958 & 0.857 & 0.739 & 0.408 & 0.298 & 0.274 \\
\hline 1 & 1 & 0.957 & 0.856 & 0.707 & 0.302 & 0.236 & 0.219 \\
\hline
\end{tabular}
values of the functions $\psi(x, k)$ to Table 1 .

Table 1. The function $\psi(x, k)$ values

Table 1 shows that the values $\psi(x, k) \in[0,1]$ for $k \in[0, \pi]$ and $x \in[0,1]$. Under these conditions, the new scheme is stable.

The approximation of the convection-diffusion problem. Consider the nonstationary convection-diffusion equation

$$
\frac{\partial q}{\partial t}+u \frac{\partial q}{\partial x}=\mu \frac{\partial^{2} q}{\partial x^{2}}
$$

where $t \in[0, T], x \in[0, L], q(0, x)=q^{0}(x), q(t, 0)=q(t, L)=0, u=$ const .

The scheme obtained as a result of a linear combination of the central difference scheme (3) and the cabaret scheme (4) will be used to approximate the convection operator 


$$
\begin{gathered}
\frac{1}{2}\left(\frac{q_{i}^{n+1}-q_{i}^{n}}{\tau}+u \frac{q_{i+1}^{n}-q_{i-1}^{n}}{2 h}-\mu \frac{q_{i+1}^{n}-2 q_{i}^{n}+q_{i-1}^{n}}{h^{2}}\right)+ \\
+\frac{q_{i}^{n+1}-q_{i}^{n}}{2 \tau}+\frac{q_{i-1}^{n}-q_{i-1}^{n-1}}{2 \tau}+u \frac{q_{i}^{n}-q_{i-1}^{n}}{h}-\mu \frac{q_{i+1}^{n}-2 q_{i}^{n}+q_{i-1}^{n}}{h^{2}}=0 ; \\
\frac{q_{i}^{n+1}-q_{i}^{n}}{\tau}+\frac{q_{i-1}^{n}-q_{i-1}^{n-1}}{2 \tau}+u \frac{q_{i+1}^{n}+4 q_{i}^{n}-5 q_{i-1}^{n}}{4 h}-3 \mu \frac{q_{i+1}^{n}-2 q_{i}^{n}+q_{i-1}^{n}}{2 h^{2}}=0 .
\end{gathered}
$$

In Figure 3, the solutions of the model problem with initial conditions $q^{0}(x)=h(20-\mathrm{x})$, where $h(\mathrm{x})$ is the Heaviside function ( 1 - the exact solution of the transfer problem, 2 - the numerical solution based on the proposed difference scheme for different values of Peclet numbers, 3 - the numerical solution of the transfer problem based on the «against» flow).
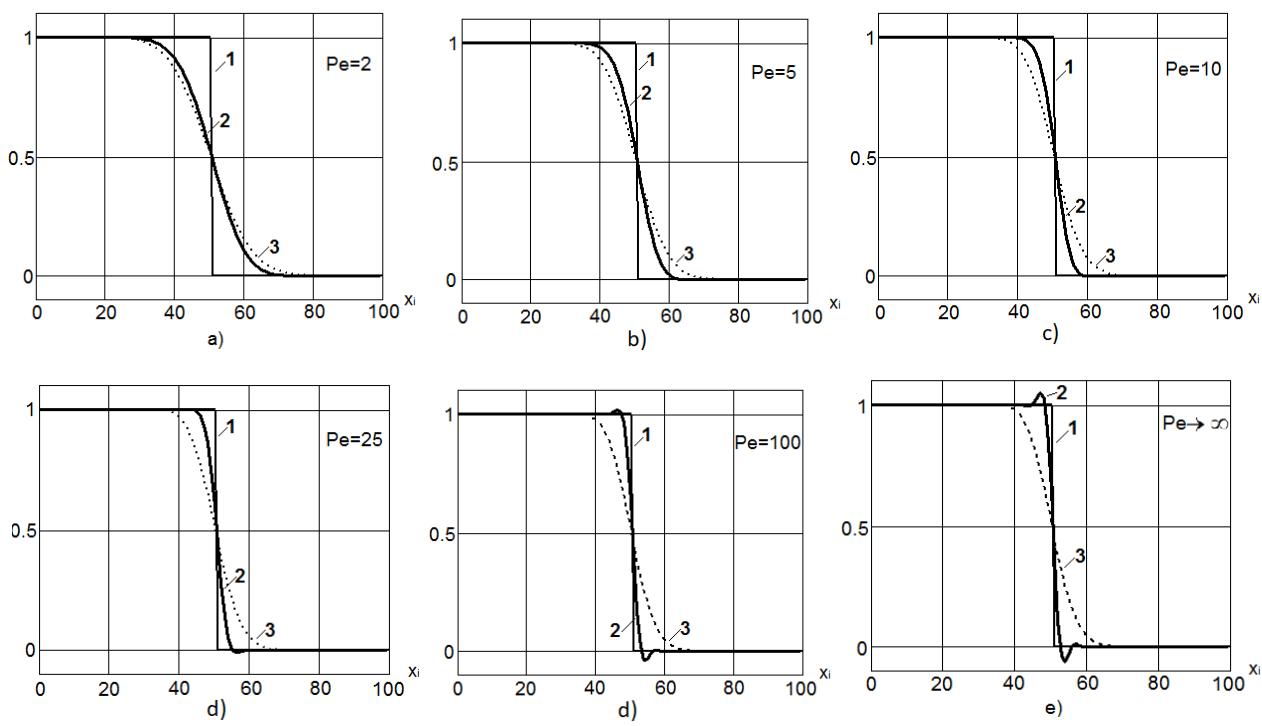

Fig. 3. The solutions of the model problem of concentrations front transport: 1 - the exact solution of the transfer problem, 2 - the numerical solution based on the proposed difference scheme for different values of Peclet numbers, 3 the numerical solution of the transfer problem based on the «against» flow

The two-dimensional diffusion-convection problem. Consider the two-dimensional convection-diffusion equation

$$
\frac{\partial q}{\partial t}+u \frac{\partial q}{\partial x}+v \frac{\partial q}{\partial y}=\mu \frac{\partial^{2} q}{\partial x^{2}}+\mu \frac{\partial^{2} q}{\partial y^{2}}
$$

where $t \in[0, T], \quad x \in\left[0, L_{x}\right], \quad y \in\left[0, L_{y}\right] \quad q(0, x, y)=q^{0}(x, y), \quad q(t, 0, y)=q\left(t, L_{x}, y\right)=0$, $q(t, x, 0)=q\left(t, x, L_{y}\right)=0$.

Cover the domain of definition by a uniform computational grid $\omega=\omega_{\tau} \times \bar{\omega}_{x} \times \bar{\omega}_{y}$, where $\bar{\omega}_{x}=\left\{x_{i} \mid x_{i}=i h_{x}, i=0,1, \ldots, N, N h_{x}=L_{x}\right\}$, $\bar{\omega}_{y}=\left\{y_{i} \mid y_{i}=i h_{y}, i=0,1, \ldots, N, N h_{y}=L_{y}\right\}$, $\omega_{\tau}=\left\{t_{j} \mid j=0,1, \ldots\right\}, \tau=t_{n+1}-t_{n}=$ const . 
The scheme (5) for equation (8) will have the form (the scheme of splitting in space)

$$
\begin{gathered}
\frac{q_{i, j}^{n+1 / 2}-q_{i, j}^{n}}{\tau}+\psi_{x L} \frac{q_{i-1, j}^{n-1 / 2}-q_{i-1, j}^{n-1}}{2 \tau}+\psi_{x R} \frac{q_{i+1, j}^{n-1 / 2}-q_{i+1, j}^{n-1}}{2 \tau}+ \\
+u \frac{q_{i+1, j}^{n}-q_{i-1, j}^{n}}{4 h_{x}}+\psi_{x L} u \frac{q_{i, j}^{n}-q_{i-1, j}^{n}}{h_{x}}+\psi_{x R} u \frac{q_{i+1, j}^{n}-q_{i, j}^{n}}{h_{x}}=\frac{3}{2} \mu \frac{q_{i+1, j}^{n}-2 q_{i, j}^{n}+q_{i-1, j}^{n}}{h_{x}^{2}} \\
\frac{q_{i, j}^{n+1}-q_{i, j}^{n+1 / 2}}{\tau}+\psi_{y L} \frac{q_{i, j-1}^{n}-q_{i, j-1}^{n-1 / 2}}{2 \tau}+\psi_{y R} \frac{q_{i, j+1}^{n}-q_{i, j+1}^{n-1 / 2}}{2 \tau}+ \\
+v \frac{q_{i, j+1}^{n+1 / 2}-q_{i, j-1}^{n+1 / 2}}{4 h_{y}}+\psi_{y L} v \frac{q_{i, j}^{n+1 / 2}-q_{i, j-1}^{n+1 / 2}}{h_{y}}+\psi_{y R} v \frac{q_{i, j+1}^{n+1 / 2}-q_{i, j}^{n+1 / 2}}{h_{y}}=\frac{3}{2} \mu \frac{q_{i, j+1}^{n+1 / 2}-2 q_{i, j}^{n+1 / 2}+q_{i, j-1}^{n+1 / 2}}{h_{y}^{2}},
\end{gathered}
$$

where $\psi_{x L}=1, \psi_{x R}=0$ for $u>0$ and $\psi_{x L}=0, \psi_{x R}=1$ for $u<0 ; \psi_{y L}=1, \psi_{y R}=0$ for $v>0$ and $\psi_{y L}=0, \psi_{y R}=1$ for $v<0$.

The simulation was performed on a grid with the dimensions $100 \times 100$ computed nodes with the follow parameters: the dimensions of the computed area $L_{x}=100 \mathrm{~m}, L_{y}=100 \mathrm{~m}$, the horizontal component is $4 \mathrm{~m} / \mathrm{c}$, vertical $-3 \mathrm{~m} / \mathrm{c}$, the turbulent exchange coefficient was set equal to: $0,0.1,0.4$, $2 \mathrm{~m}^{2} / \mathrm{c}$. In solving the two-dimensional convection-diffusion problem, the initial distribution was given by the function [4]:

$$
q(x, y)=\left\{\begin{array}{l}
\sin (\pi(x-10) / 10) \sin (\pi(y-10) / 10),\{x, y\} \in D, \\
0,\{x, y\} \notin D, \\
D:\{x \in[10,20], y \in[10,20]\}
\end{array}\right.
$$

The numerical solution of the convection problem with help of the difference scheme (9) - (10) at different time intervals is shown in Fig. 4.
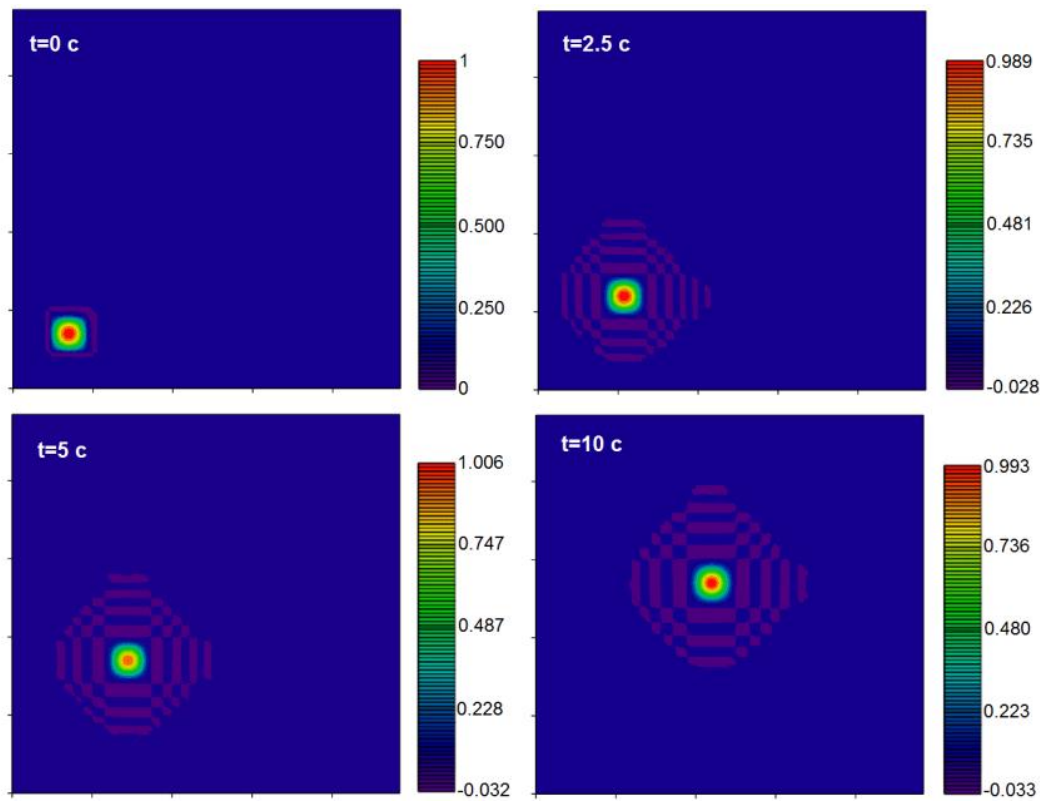

Fig. 4. The numerical solution of the convection problem using the scheme (5) at different time intervals 
Figures 5 and 6 show the numerical solutions of the convection-diffusion problem for various Peclet numbers using the «CABARET» scheme and the scheme (5).
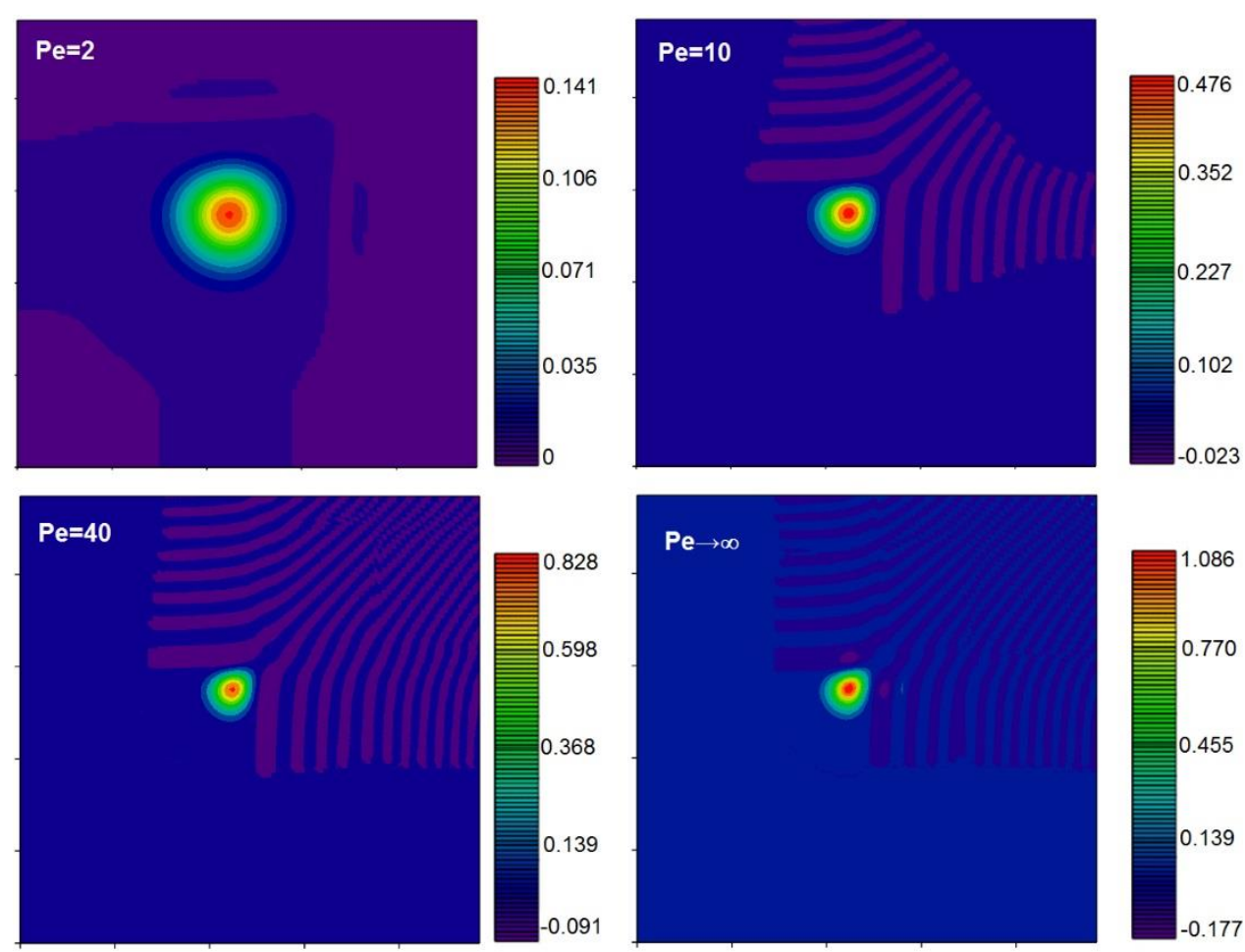

Fig. 5. The numerical solution of the convection-diffusion problem for various Peclet numbers using the «CABARET» scheme
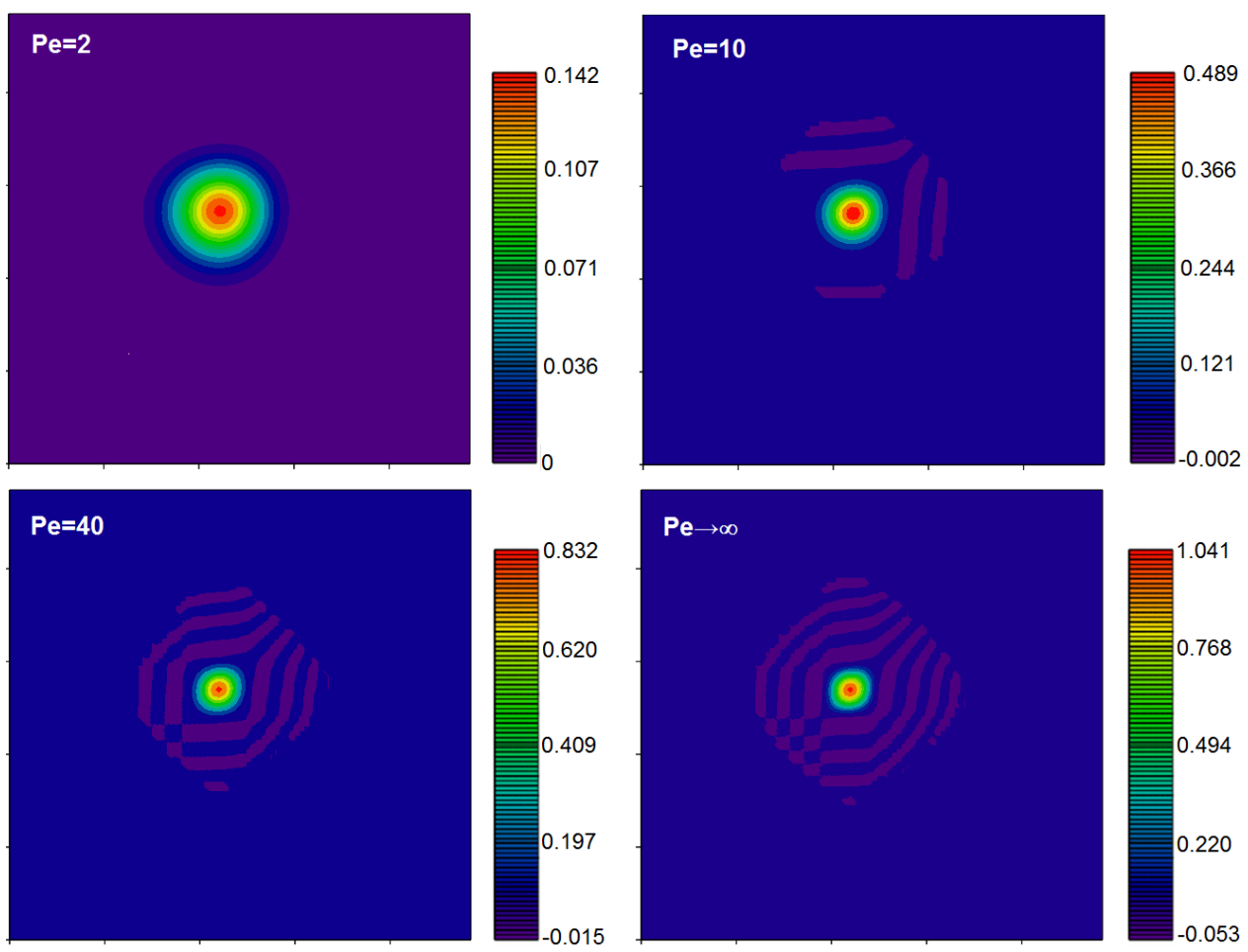

Fig. 6. The numerical solution of the convection-diffusion problem for various Peclet numbers using the scheme (5) 
The limiting absolute error in solving the convection problem with help of the «CABARET» scheme is 0.281 units, and using the scheme (5), 0.125 units. Thus, when $P e \rightarrow \infty$ the error in the numerical solution of the model problem (11) with help of the difference scheme (5) is 2.248 times less than the error in solving with help of the «CABARET» scheme. Figure 7 shows the errors of the numerical solution of the convection problem for various schemes.

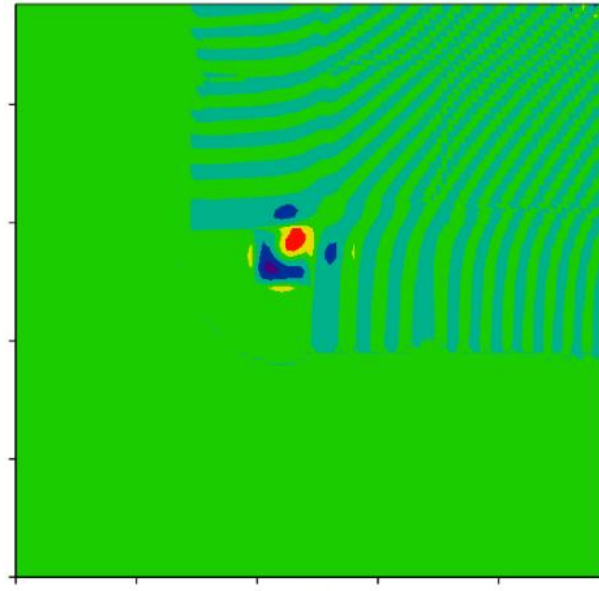

a)

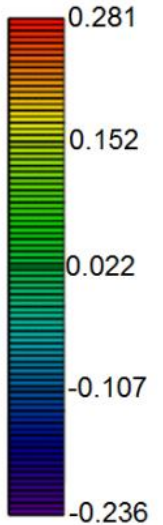

0.236

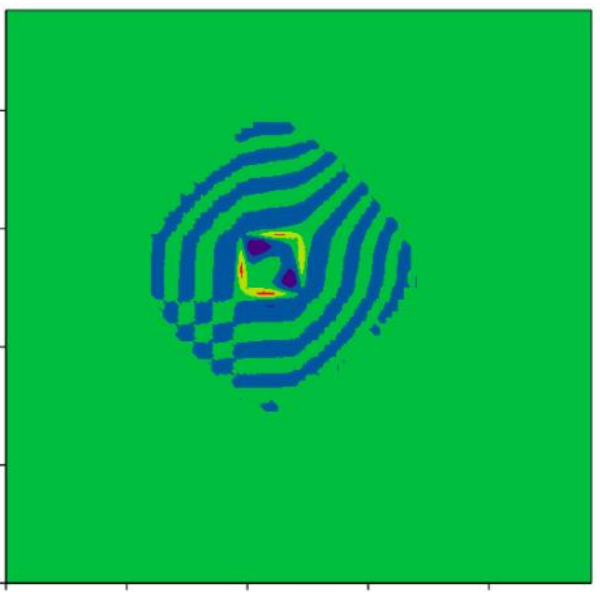

b)

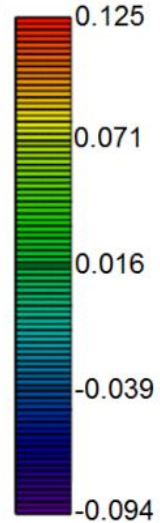

0.094

Fig. 7. The error in the numerical solution of the convection problem $(\mu=0, P e \rightarrow \infty)$ using a) the «CABARET» scheme and b) the scheme (5)

When modeling applied problems, such as the problem of hydrodynamics of shallow water bodies, aerodynamics, population dynamics and others, it is necessary to solve the convectiondiffusion equations. If the problem poses the condition for the predominance of convection over diffusion, then the standard schemes have a low accuracy. The paper proposes a three-layer difference scheme for the convection-diffusion equation, which is a linear combination of the «CABARET» scheme and the central difference scheme. It is shown that the new scheme is stable for Courant numbers belonging to the interval $[0,1]$ and large Peclet numbers $(P e>20)$. An investigation of the numerical solution of the two-dimensional convection-diffusion equation in the limiting case (the diffusion coefficient is zero) shows that for large Peclet numbers the error in the numerical solution of the model problem based on the proposed difference scheme is 2.248 times smaller than the error in solving with the «CABARET» scheme.

The results of the study and their discussion. The developed model, the algorithms that implement it, and the constructed software complex allowed to carry out the numerical experiments to simulate the propagation of pollutants in the ground layer of the atmosphere in the presence of forest massifs. The influence of the presence of vegetation on the distribution of pollutants under the action of ascending air currents was studied. Initial data: air density is $1.29 \mathrm{~kg} / \mathrm{m}^{3}$; density of emission is $1.4 \mathrm{~kg} / \mathrm{m}^{3}$; ambient temperature is $200^{\circ} \mathrm{C}$; emission temperature is $1200^{\circ} \mathrm{C}$; speed of air flow is 1 $\mathrm{m} / \mathrm{s}$ in the direction of the coastal area; specific emission power is $5 \mathrm{l} / \mathrm{s}$; air velocity at the left boundary is $1 \mathrm{~m} / \mathrm{s}$; air permeability coefficient of the vegetative cover is $50 \%$; the height of the vegetation cover is $30 \mathrm{~m}$, the width of the vegetation cover area is $50 \mathrm{~m}$. The palette shows the concentration of the impurity. Numerical experiments have been performed to simulate the movement 
of pollutants in the presence of forest plantations (Fig. 2) and in the absence of them (Fig. 8). The area of forest plantations is indicated by a rectangle.

The color gradation illustrates the concentration of the impurity. Analysis of fig. 8 allows to conclude that the presence of forest plantations influences the distribution of pollutants. Impurities under the influence of ascending air currents rise in the area of forest plantations. Fig. 9.a shows the movement of the air in the presence of forest plantations. Gradation of color shows the intensity of the air movement.

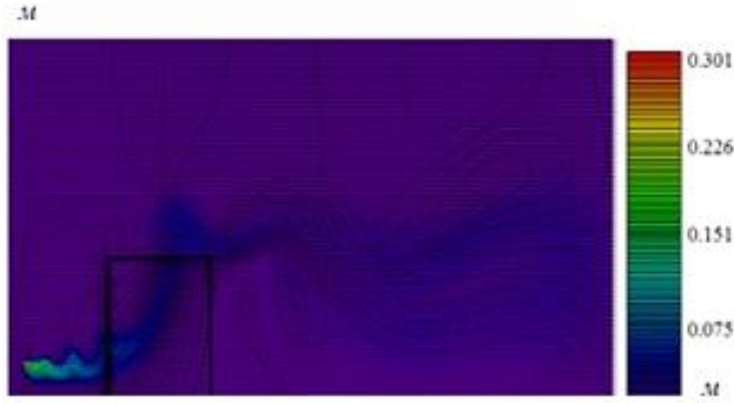

a)

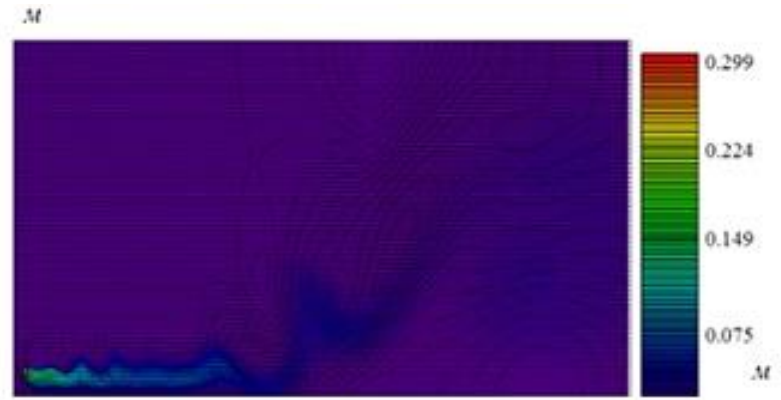

b)

Fig. 8. The field of impurity concentrations taking into account vegetation (a) and without them (b)

Fig. 8 illustrates the speed field of the air in the presence of forest plantations and the vortex structures of the air flow located beyond the forest plantations in the direction of the wind movement. The speed of air movement is increased three times in separate areas.

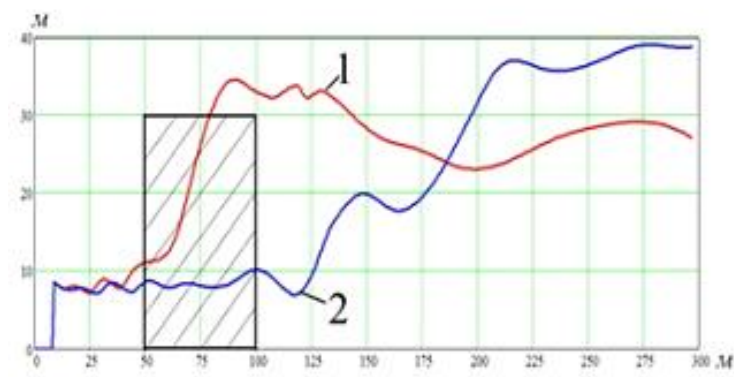

a)

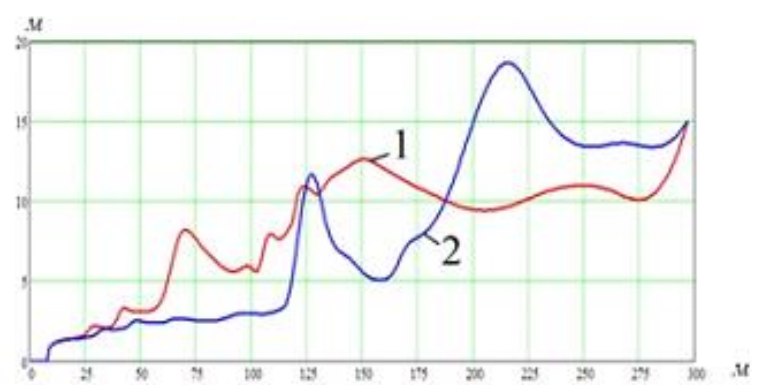

b)

Fig. 9. Trajectories for the distribution of pollutants taking into account vegetation (a) and without them (b)

Fig. 9.a shows the decrease in the width of the current tube in the area of forest plantations. Figure 9.b shows the speed field of the air in the case of forest plantations. A palette shows the intensity of the air movement.

The presence of forest plantations affects the distribution of pollutants. Impurities under the influence of ascending air currents rise in the area of forest plantations. Figure 9.a shows the trajectories of pollutants: 1 - the presence of a semipermeable area, 2 - the absence of a semipermeable area. Fig. 9.b shows the dependence of the width of the current tubes, over which the pollutants spread, in the case of a semipermeable region and its absence. 


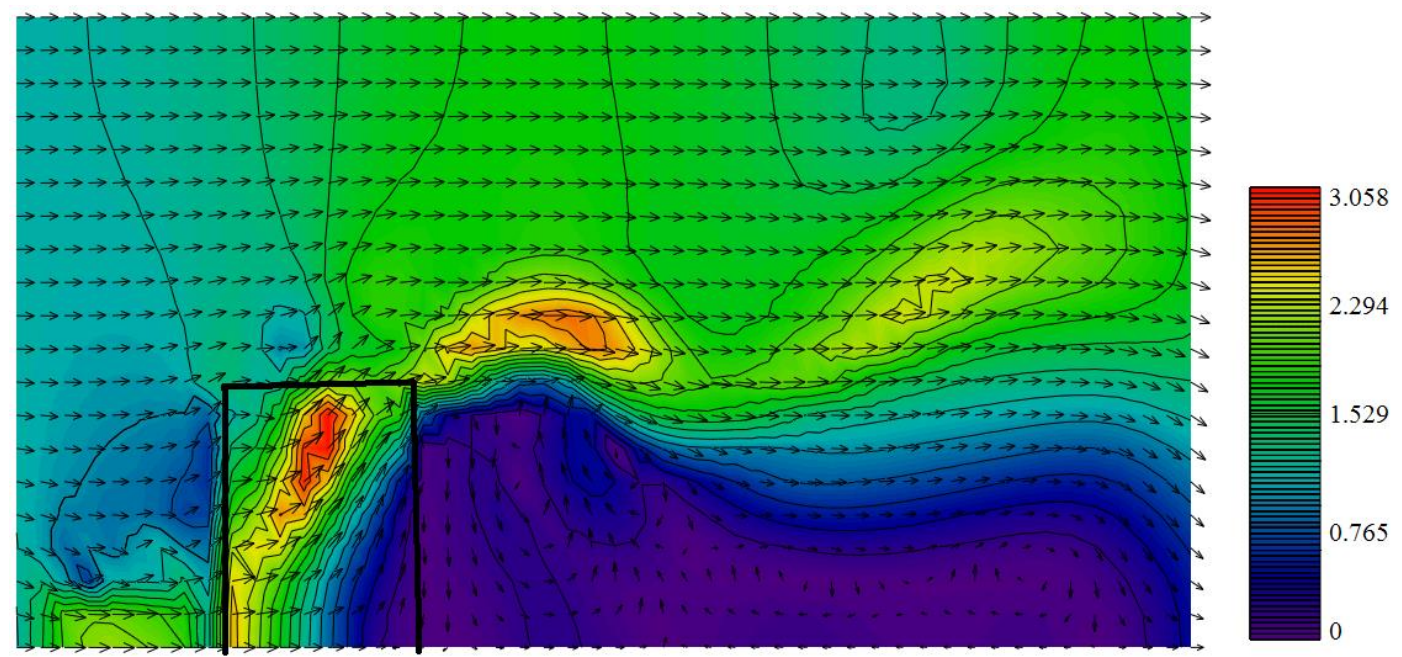

Fig. 10. Movement of the air in the presence of forest plantations

Fig. 10 illustrates the vortex structures of the air flow, located beyond the forest plantations in the direction of wind movement. The speed of air movement is increased three times in separate areas. Next, the influence of the width of the forest plantations area on the air velocity and impurity concentration fields was investigated.

Conclusions. The proposed methods of mathematical modeling of the motion of air currents enable to evaluate the influence of forest plantations on the propagation of pollutants in the ground layer of the atmosphere and the change in the coefficient of turbulent exchange. The developed model takes into account the transition of water from liquid to gaseous state, precipitation of matter, transport of impurities and heat, heat exchange between liquid and gaseous states.

The scientific novelty of the presented results is that the scheme obtained as a result of a linear combination of the central difference scheme and the «CABARET» scheme was used for the approximation of the convection operator. The use of «CABARET» schemes allows to increase the conditions for the applicability of the developed model. The constructed algorithms are implemented in the form of a software complex that allows to determine the influence of the presence of vegetation on the distribution of pollutants under the influence of ascending air currents. The developed model, the algorithms that implement it, and the constructed software complex allowed the numerical experiments to simulate the propagation of pollutants in the ground layer of the atmosphere in the presence of forest massifs. The advantage of the model of the air environment motion is the possibility of taking into account the influence of forest massifs and turbulent mixing in the equation of continuity of the medium. 


\section{References}

1. Sukhinov, A.I., Chistyakov, A.E., Alekseenko, E.V. (2011) Mathematical Models and Computer Simulations, 3(5), c. 562-574.

2. Sukhinov, A.I., Sukhinov, A.A. Reconstruction of 2001 Ecological Disaster in the Azov Sea on the Basis of Precise Hydrophysics Models (2005) Parallel Computational Fluid Dynamics 2004: Multidisciplinary Applications, pp. 231-238.

3. Vasiliev, V.S., Sukhinov, A.I. (2003) Matem. Modelling, 15 (10), pp. 17-34.

4. Leontyev, I.O. (2001) Coastal Dynamics: Waves, Moving Streams, Deposits Drifts GEOS, Moscow.

5. Alekseenko, E., Roux, B., Sukhinov, A., Kotarba, R., Fougere, D. Nonlinear hydrodynamics in a mediterranean lagoon (2013) Nonlinear Processes in Geophysics, 20 (2), pp. 189-198.

6. Sukhinov, A.I., Chistyakov, A.E., Protsenko, E.A. Mathematical modeling of sediment transport in the coastal zone of shallow reservoirs (2014) Mathematical Models and Computer Simulations, 6 (4), pp. 351-363.

7. A.I. Sukhinov, Yu.V. Belova, A.E. Chistyakov Solution of the matter transport problem at high Peclet numbers // Vychislitelnye metody i programmirovanie, 2015, V. 18, №. 4, p. 371-380.

8. V.A. Gushchin Family of quasi-monotonic finite-difference schemes of the second-order of approximation // Math. Models and Comp. Simulations, 2016, V. 8, № 5, p. 487-496.

9. O.M. Belotserkovskii, V.A. Gushchin, V.N. Kon'shin The splitting method for investigating flows of a stratified liquid with a free surface // USSR Computational Mathematics and Mathematical Physics, 1987, V. 27, № 2, p. 181-191.

10. A.A. Samarskiy, P.N. Vabishchevich Numerical methods for solving convectiondiffusion problems. - M.: Editorial URSS, 1999.

11. V.M. Goloviznin, A.A. Samarskii Finite difference approximation of convective transport equation with space splitting time derivative // Math. Models and Comp. Simulations, 1998, v. 10, № 1, p. 86-100.

12. Marchuk, G.I., Agoshkov, V.I. (1981) Introduction to Projection-grid Methods (Science. The Main Edition of Physics and Mathematics, Moscow.

13. Vaseva, I.A., Kofanov, A.V., Liseikin, V.D., Likhanova, Y.V., Kharitonchik, A.M. (2010) Vychislitel'noi Matematiki i Matematicheskoi Fiziki, 50 (1), pp. 99-117.

14. Samarskii, A.A., Gulin, A.V. (2003) Numerical Methods of Mathematical Physics. 2nd ed. (The scientific world, Moscow.

15. Belotserkovsky, O.M. (2004) Numerical Modeling at Mechanics Continuous Environments. Fizmatlit, Moscow.

16. Chetverushkin, B.N. Resolution limits of continuous media mode and their mathematical formulations (2013) Mathematical Models and Computer Simulations, 5 (3), pp. 266279.

17. Sukhinov, A.I., Chistyakov, A.E., Timofeeva, E.F., Shishenya, A.V. Mathematical model for calculating coastal wave processes (2013) Mathematical Models and Computer Simulations, 5 (2), pp. 122-129. 
18. Belotserkovskii, O.M. (2003) Turbulence: New Approaches. Nauka, Moscow.

19. Samarskii, A.A. (1989) The Theory of Difference Schemes. Science, Moscow.

20. Belotserkovskii, O.M., Gushchin, V.A., Shchennikov, V.V. Use of the splitting method to solve problems of the dynamics of a viscous incompressible fluid (1975) USSR Computational Mathematics and Mathematical Physics, 15 (1), pp. 190-200.

21. Nikitina, A.V., Sukhinov, A.I., Ugolnitsky, G.A., Usov, A.B., Chistyakov, A.E., Puchkin, M.V., Semenov, I.S. Optimal control of sustainable development in the biological rehabilitation of the Azov Sea (2017) Mathematical Models and Computer Simulations, 9 (1), pp. 101-107.

22. Sukhinov, A.I., Chistyakov, A.E., Levin, I.I., Semenov, I.S., Nikitina, A.V., Semenyakina, A.A. Solution of the problem of biological rehabilitation of shallow waters on multiprocessor computer system (2016) 2016 5th International Conference on Informatics, Electronics and Vision, ICIEV 2016, art. no. 7760175, pp. 1128-1133.

23. Sukhinov, A., Chistyakov, A., Nikitina, A., Semenyakina, A., Korovin, I., Schaefer, G. Modelling of oil spill spread (2016) 2016 5th International Conference on Informatics, Electronics and Vision, ICIEV 2016, art. no. 7760176, pp. 1134-1139.

24. Sukhinov, A.I., Khachunts, D.S., Chistyakov, A.E. A mathematical model of pollutant propagation in near-ground atmospheric layer of a coastal region and its software implementation (2015) Computational Mathematics and Mathematical Physics, 55 (7), pp. 1216-1231.

25. Sukhinov, A.I., Chistyakov, A.E., Shishenya, A.V. Error estimate for diffusion equations solved by schemes with weights (2014) Mathematical Models and Computer Simulations, 6 (3), pp. 324-331.

26. Buzalo, N., Ermachenko, P., Bock, T., Bulgakov, A., Chistyakov, A., Sukhinov, A., Zhmenya, E., (...), Zakharchenko, N. Mathematical modeling of microalgae-mineralization-human structure within the environment regeneration system for the biosphere compatible city (2014) Procedia Engineering, 85, pp. 84-93.

27. Sukhinov, A.I., Chistyakov, A.E. Adaptive modified alternating triangular iterative method for solving grid equations with a non-self-adjoint operator (2012) Mathematical Models and Computer Simulations, 4 (4), pp. 398-409.

\section{Authors:}

Belova Yuliya Valeriyevna, Don State Technical University (1 Gagarin sq., Rostov-on-Don, Russian Federation), Research engineer

Protsenko Elena Anatolevna, Taganrog Institute of A.P. Chekhov (branch) RSUE (Initiative Street, Taganrog, Russian Federation), Candidate of Science in Physics and Maths, Associate professor

Atayan Asya Mikhailovna, Don State Technical University (1st Gagarin Square, Rostov-on-Don, Russian Federation), postgraduate student

Kurskaya Inna Aleksandrovna, Don State Technical University (1st Gagarin Square, Rostov-onDon, Russian Federation), postgraduate student 


\section{Моделирование прибрежной аэродинамики с учетом лесных насаждений*}

\section{Ю.В. Белова**, Е.А. Проценко**, А.М. Атаян, И.А. Курская**}

Донской государственный технический университет, Ростов-на-Дону, Российская Федерация Таганрогский институт им. А.П. Чехова (филиал) РГЭУ (РИНЭ), Таганрог, Россия

Целью работы является исследование влияния лесных насаждений на распределение загрязняющих веществ в приземном слое атмосферы. Модель учитывает различные факторы: наличие лесных насаждений, изменения давления, плотности и температуры, наличие многокомпонентной примеси и др. Схема, полученная в результате линейной комбинации центральной разностной схемы и схемы «кабаре», построена для аппроксимации оператора конвекции. Использование схемы «кабаре» позволило разработать математическую модель, обладающую устойчивостью для более широкого класса входных параметров. Программный комплекс позволяет определить влияние лесных насаждений на распределение загрязняющих веществ под влиянием восходящих воздушных потоков. Разработанная модель, алгоритмы ее реализации и построенный программный комплекс позволили провести численные эксперименты, моделирующие распределение загрязняющих веществ при наличии лесных насаждений. Изучено влияние наличия насаждений на распределение загрязняющих веществ под действием восходящих воздушных потоков. Анализ результатов численных экспериментов позволяет сделать вывод, что на распределение загрязняющих веществ в многокомпонентной воздушной среде существенно влияет плотность растительности.

Ключевые слова: численное моделирование, центральная разностная схема, схема «кабаре», оператор конвекции

Авторы:

Белова Юлия Валериевна, инженер, Донской государственный технический университет (344000 Ростов-на-Дону, пл. Гагарина, д. 1)

Проценко Елена Анатольевна, Таганрогский институт им. А.П. Чехова (филиал) РГЭУ (РИНЭ) (347936 Таганрог, улица Инициативная, д. 48), кандидат физико-математических наук

Атаян Ася Михайловна, Донской государственный технический университет (344000 Ростов-на-Дону, пл. Гагарина, д. 1), аспирант

Курская Инна Александровна, Донской государственный технический университет (344000 Ростов-на-Дону, пл. Гагарина, д. 1), аспирант

\footnotetext{
* Работа выполнена при поддержке РНФ, проект № 17-11-01286.

** E-mail: yvbelova@yandex.ru.

${ }^{* * *}$ E-mail: eapros@rambler.ru.
} 